\title{
Atypical leukaemia of long duration with monoclonal hypergammaglobulinaemia
}

\author{
M. CONSTANTOULAKIS, E. PHOCAS, AND G. THEODOROPOULOS
} From the First Medical Clinic, University of Athens, and Blood Research Laboratory, Hellenic Red Cross.

SYNOPSIS A patient with atypical acute leukaemia is described. This patient has, in addition $\vec{Z}$ monoclonal IgG hyperglobulinaemia without myelomatous lesions and is living and well three years after diagnosis.

The cell types found in the blood and in the bone marrow are atypical, and the histochemicake findings are discussed.

The relationship between monoclonal hypergammaglobulinaemia and malignant bloodo diseases is also discussed, and the literature on the subject reviewed.

Recently it has become clear that monoclonal hypergammaglobulinaemia is not necessarily diagnostic of myeloma or Waldenström's macroglobulinaemia. Thus, it has been found in asymptomatic persons by Fine (1967) in approximately $2 \%$ of the population over 60 years of age and in $0.4 \%$ under the age of 60 . This type of abnormality has been called 'benign' or 'essential idiopathic monoclonal hypergammaglobulinaemia'. It has also been described in association with different neoplastic and non-neoplastic diseases (Danon, Clauvel, and Seligmann, 1967; Fine, 1967; Hällen, 1966; and Waldenström, 1964).

The association with malignant blood diseases is not so rare. It has been found frequently enough in chronic lymphocytic leukaemia, lymphosarcoma, reticulum cell sarcoma, and Gaucher's disease (Azar, Hill, and Osserman, 1957; Hällen, 1966; Pratt, Estren, and Kochwa, 1968). On the contrary, the presence of monoclonal hypergammaglobulinaemia in polycythaemia, myelofibrosis, myelofibrosis with myeloid metaplasia, osteomyelosclerosis, chronic myeloid leukaemia, erythraemic myelosis, and acute leukaemia is very rare (Baldini, Fudenberg, Fukutka, and Dameshek, 1959; Brody, Beizer,

Please address requests for reprints to $M$. Constantoulakis, 4, Alkiviadou str., Athens, 109.

Received for publication 23 April 1969. and Schwartz, 1964; Ritzmann, Stoufflet, Houston, and Levin, 1966).

We have studied a patient who has an atypica form of acute leukaemia and monoclonal hyper gammaglobulinaemia (IgG type $\lambda$ ) and is living and well three years after the initial diagnosis.

\section{Case Report}

The patient, a 63-year-old farmer, was admitted to hospital in April 1965 with the chief complaints of pain in the lower extremities aggravated by physical work and of a feeling of tickling. He alsow complained of loss of appetite and of weighto weakness, lassitude, and a low-grade fever in the afternoons.

Physical examination showed a pale, well groomed, rather thin man. Neither the lympho nodes, liver, nor spleen were palpable. No pete? chiae or haematomas were seen. A complete neurological examination was unrevealing. Ar$\stackrel{\vec{D}}{\mathbb{Q}}$ terial pulses were found in the lower extremities

Urine analysis gave protein $0.10 \%$; blood urea was $0.29 \%$; blood cholesterol, $153 \mathrm{mg} \%$ (esterifiec $90 \mathrm{mg} \%$ ); thymol turbidity, 7 units; $\mathrm{ZnSO}^{-}$ turbidity, 23 units; cephalin-cholesterol floccus lation, $2+$; prothrombin time, $13 / 13 \mathrm{sec}$; tota $\vec{\Gamma}$ 


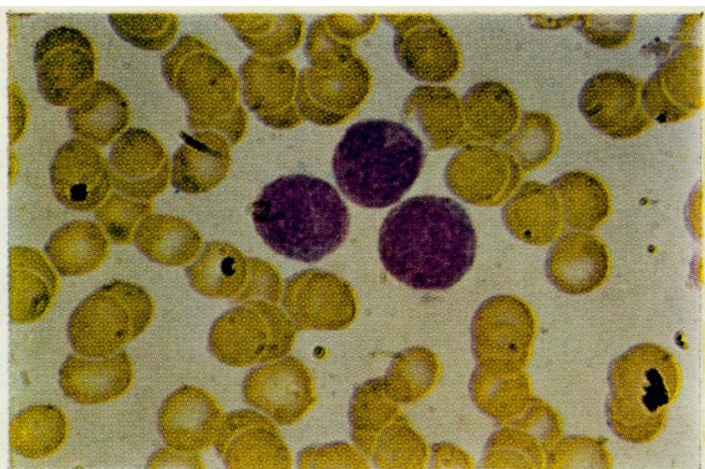

Fig. 1 Atypical cells of the peripheral blood.

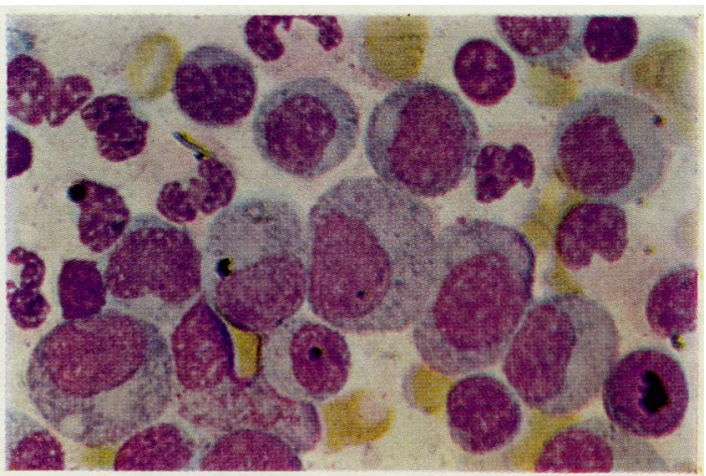

Fig. 2

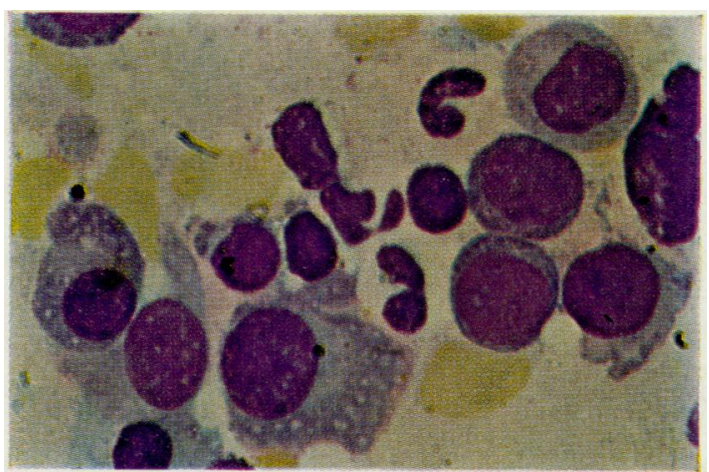

Fig. 3

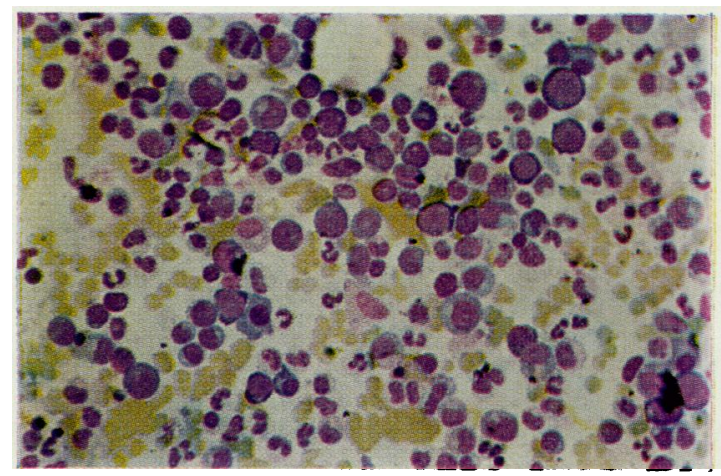

Fig. 4

Figs. 2, 3, and 4 Myeloblasts and premyelocytes (Figs 2 and 4) and plasma cells (Fig. 3 ) in the bone marrow. serum bilirubin $0.45 \mathrm{mg} \%$; bromsulphalein retention $4 \%$ after 45 min; R.A. test, $1+$; C-reactive protein $1+$; Rose-Waaler and L.E. cell tests negative; direct Coombs test, negative; Wassermann reaction, negative; Sia test, $1+$; urine creatinine clearance, $90 \mathrm{ml} / 1 / \mathrm{min}$; total serum proteins $7.6 \mathrm{~g} \%$ (albumin $4 \mathrm{~g} \%$, globulin $3.6 \mathrm{~g} \%$ ); ESR, $80 \mathrm{~mm}$; haemoglobin $10 \cdot 1 \mathrm{~g} \%$; haematocrit, $33 \%$; white blood cell count, $6.000 / \mathrm{mm}^{3}$; platelet count, $130 \cdot 000 / \mathrm{mm}^{3}$.

The differential white cell count showed the presence of 50 to $60 \%$ atypical mononuclear cells, $10 \%$ of which had the appearance of immature cells with nucleoli. These mononuclear cells were fairly large with grey or pale blue cytoplasm and very few or no granules. The nucleus was large and in most of the cells it was irregular and folded (Figure 1). Serum cellulose acetate electrophoresis gave a sharp and narrow band in the gamma globulin region. Routine radiographs of the chest and the digestive tract were negative. Also negative was a complete skeletal $x$-ray survey.

Repeated bone marrow aspirations during the patient's stay in hospital showed a cellular marrow with a significant increase $(50 \%$ of the white cells) in the numbers of premyelocytes and myeloblasts (Figures 2 and 4). The plasma cells were also increased ( $8 \%$ approximately) and some of them were large and immature (Figure 3). Also present were several immature cells with a pale blue, somewhat vacuolated cytoplasm without granules and a large, eccentric mucleus usually without nucles)li but with fine chromatin structure. These cells did not resemble the mononuclear cells of the peripheral blood and had some of the characteristics either of atypical premyelocytes or of atypical immature plasma cells. Red cell precursors were relatively diminished and megakaryocytes were present in normal numbers.

The patient was transfused with 2 units of blood $(900 \mathrm{ml})$ and was given parenterally $30 \mathrm{mg}$ prednisolone per day. He improved quickly and symptoms were relieved. Prednisolone was continued for two months, after which 6-mercaptopurine was administered, $100 \mathrm{mg}$ per day. For the next 18 months he was taking 50-100 mg 6-mercaptopurine and was feeling well. The liver, the spleen, and the lymph nodes were not palpable and blood counts remained the same (Table I). Multiple marrow aspirations at various intervals did not show any significant changes. New radiographs of the skeleton in 1968 were again negative. During the last 14 months the patient has stopped taking 6-mercaptopurine and his condition is still unchanged.

Because the routine tests disclosed abnormalities in the peripheral blood cell counts in the bone marrow cells and in the serum proteins, further more detailed investigations were carried out.

Serum cellulose acetate electrophoresis (Kohn, 1960) and immunoelectrophoresis (Nerenberg, 


\begin{tabular}{lcclcl}
\hline Date & $H b(\mathrm{~g} \%)$ & $H t(\%)$ & $\begin{array}{l}\text { White Blood } \\
\text { Cells } / \mathrm{mm}^{3}\end{array}$ & Platelets/mm & $\begin{array}{l}\text { Atypical } \\
\text { Cells }(\%)\end{array}$ \\
\hline 19.4 .65 & $10 \cdot 1$ & 33 & 6.000 & 130.000 & 65 \\
9.5 .65 & $9 \cdot 8$ & 32 & 4.100 & 120.000 & 67 \\
22.5 .65 & $11 \cdot 1$ & Transfusion of $900 \mathrm{ml}$ whole blood & \\
12.10 .65 & $11 \cdot 7$ & 46 & 3.600 & 125.000 & 53 \\
2.6 .66 & 13 & 43 & 8.700 & 180.000 & 50 \\
19.4 .67 & 12.8 & 43 & 6.200 & 235.000 & 41 \\
2.4 .68 & $11 \cdot 8$ & 38 & 6.000 & 185.000 & 59 \\
\hline
\end{tabular}

Table I Follow-up blood counts

1966) were performed. Antisera for IEP, IgG, IgA, and IgM globulins, and for types $\mathrm{K}$ and $\mathrm{L}$ Bence-Jones proteins were utilized. ${ }^{1}$ Ultracentrifugation of serum was performed using a Spinco model E analytical ultracentrifuge. Chromosomal studies of the bone marrow cells were performed with the direct method (Kiossoglou, Mitus, and Dameshek, 1964) before treatment was begun. Quantitative estimations of serum immunoglobulins ${ }^{2}$ were performed using the single radial diffusion method (Mancini, Vaerman, Carbonara, and Heremans, 1964).

For the peroxidase stain the classic method of Gomori (1953) was used and for the non-specific esterase and the periodic acid-Schiff stains the methods described by Hayhoe, Quaglino, and Doll (1964) were used. The methyl-green pyronin stain was used as a nucleic acid differential stain (Perry and Reynolds, 1956).

The results of using special stains for the peripheral blood and bone marrow cells are shown in Table II. It must be emphasized that the peroxidase stain gave positive results with the numerous premyelocytes and myeloblasts. Methyl

${ }^{1}$ Hyland Laboratories, Los Angeles, California.

${ }^{2}$ Immunoplates, Hyland Laboratories.

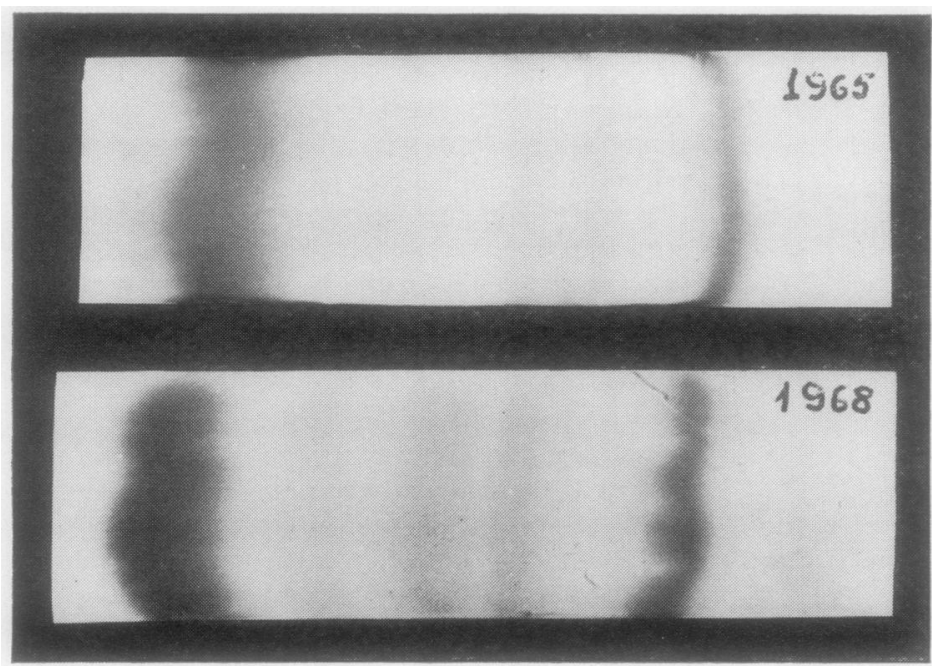

Fig. 5 Cellulose acetate electrophoresis of the blood serum.

\begin{tabular}{|c|c|c|}
\hline Special Stain & $\begin{array}{l}\text { Mononuclear } \\
\text { Blood Cells }\end{array}$ & $\begin{array}{l}\text { Atypical } \\
\text { Marrow Cells }\end{array}$ \\
\hline Peroxidase & $\begin{array}{l}\text { Negative or } \\
\text { weak positive }\end{array}$ & Negative \\
\hline $\begin{array}{l}\text { Methyl green pyronin } \\
\text { PAS/methyl green or } \\
\text { PAS/haematoxylin }\end{array}$ & $\begin{array}{l}\text { Negative } \\
\text { Negative }\end{array}$ & $\begin{array}{l}\text { Negative } \\
\text { Negative }\end{array}$ \\
\hline Non-specific esterase & $\begin{array}{l}\text { Weak positive } \\
\text { or positive }\end{array}$ & Not done \\
\hline
\end{tabular}

Table II Special stains for mononuclear blood cells and atypical marrow cells

green pyronin stained strongly the mature and immature marrow plasma cells and the PAS $\vec{\phi}$ methyl green or haematoxylin stained only the metamyelocytes and the polymorphs of the marrow and the blood. The morphology an $\frac{\text { क }}{0}$ the relative numbers of the described cells in the blood and in the bone marrow remained more of less stable during the three years during which the patient was followed up and the histochemicas results were also similar whenever done.

Chromosome analysis of the bone marrow cells did not reveal any numerical or structuras abnormalities of the chromosomes.

Electrophoresis on paper and on cellulose acetate strips gave a narrow band in the gammaes globulin region, which became more prominens with time (Figure 5). The analytic ultracentrifugation performed in 1965 showed that the 7S fraco tion was $25 \%$ of the total protein. Immunoelectro phoresis showed an abnormal precipitation line for IgG globulin. The arc was thicker, mor elongated, and slightly deviated from the normat position (Figure 6). This abnormality was more apparent when anti-IgG was used instead of whole antiserum. Quantitative estimation of the immunoglobulins gave a distinct, gradual in crease in IgG globulin during the three years of observation while a decline in IgM and IgA was noted (Table III). It becomes apparent from. Table III that the increase in IgG globulin para? leled the increase in the total proteins and glo bulins. In the 1967 serum sample the IgG globuli? was isolated and tested with antisera for $\kappa$ and chains. Precipitation lines were observed with the. anti- $\lambda$ serum only, thus proving the monoclonaly nature of the abnormal IgG globulin. BenceJones proteinuria was never found but on one occasion urine paper electrophoresis after conso centration of the urine 100 times showed a weaE band in the gamma-globulin region.

\section{Discussion}

The patient described had several atypical chara\& teristics. The long, benign course of the disease, which still continues, despite the withdrawal of specific treatment and the persistence of leukaemre cells, is uncommon. Also uncommon is the laces. of any clinical manifestations such as enlargement 


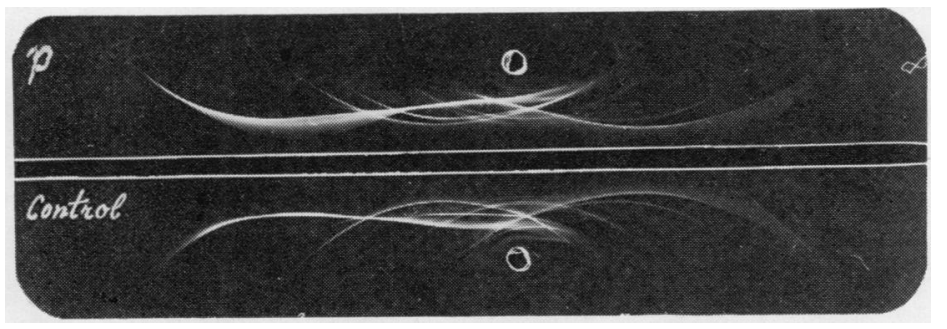

Fig. 6 Serum immunoelectrophoresis.

\begin{tabular}{|c|c|c|c|c|c|c|}
\hline \multirow[t]{2}{*}{ Date } & \multicolumn{3}{|c|}{ Proteins $(\mathrm{g} \%)$} & \multicolumn{3}{|c|}{ Immunoglobulins ( $\mathrm{g} \%)$} \\
\hline & Total & Albumin & Globulin & $\operatorname{Ig} G$ & $\operatorname{Ig} A$ & $\operatorname{Ig} M$ \\
\hline $\begin{array}{l}\text { April } 1965 \\
\text { October } 1965 \\
1966 \\
1967 \\
1968\end{array}$ & $\begin{array}{l}7 \cdot 6 \\
8 \cdot 3 \\
8 \cdot 7 \\
9 \cdot 4 \\
9 \cdot 2\end{array}$ & $\begin{array}{l}4 \\
4 \cdot 4 \\
4 \cdot 6 \\
4 \cdot 7 \\
4 \cdot 5\end{array}$ & $\begin{array}{l}3 \cdot 6 \\
3.9 \\
4 \cdot 1 \\
4 \cdot 7 \\
4 \cdot 7\end{array}$ & $\begin{array}{l}2 \cdot 1 \\
\frac{7}{2 \cdot 3} \\
2 \cdot 8 \\
3 \cdot 0\end{array}$ & $\begin{array}{l}0.3 \\
0 \cdot 21 \\
0 \cdot 225 \\
0 \cdot 165\end{array}$ & $\begin{array}{l}0 \cdot 19 \\
-0 \cdot 12 \\
0 \cdot 14 \\
0 \cdot 156\end{array}$ \\
\hline Normal values & $6 \cdot 5-8$ & $4-5 \cdot 2$ & $1 \cdot 3-2 \cdot 7$ & $0 \cdot 7-1 \cdot 4$ & $0 \cdot 15-0 \cdot 4$ & $0 \cdot 05-0 \cdot 11$ \\
\hline
\end{tabular}

Table III Follow-up analysis of serum proteins and immunoglobulins

of the liver, spleen, or lymph nodes, bleeding episodes, and marked anaemia. The patient's moderate anaemia when first examined improved after the administration of prednisolone and 6mercaptopurine. There are many cases of long survival in premyelocytic and monocytic leukaemia (Blair, Bayrd, and Pease, 1966; Burchenal, 1965; Fairbanks, Shanbrom, Steinfeld, and Beutler, 1968), but in these patients the disease was symptomatic and remissions occurred only after vigorous therapy with relapses in between. During remissions the leukaemic cells disappeared.

The atypical cells present in the blood of our patient had the morphology of monocytes and differed from both the typical blasts and premyelocytes and the atypical immature cells of the bone marrow. In no instance were myeloblasts or premyelocytes as seen in the marrow found in the peripheral blood. The monocytoid cells in the blood were as a rule morphologically mature cells, but only $10 \%$ had the characteristics of immaturity (nucleoli, fine chromatin of the nucleus, or bluish protoplasm).

The various histochemical stains used both on the blood and the marrow smears did not clarify the nature of the atypical cells. It seems improbable that the cells are monoblasts since the PAS reaction was negative, although the weakly positive peroxidase reaction and the positive reaction for non-specific esterase favour the monocytic nature of these cells. The morphological discrepancies are probably due to the simultaneous presence of typical plasma cells both mature and immature; typical myeloblasts and premyelocytes in the marrow which infiltrate most of the marrow cavity and a few are also present in the peripheral blood; typical and mainly atypical monocytes that comprise most of the cells of the peripheral blood and are also present in the marrow in small numbers. These monocytes are not leukaemic, their significance is obscure, and they are often found in acute leukaemia (Lortholary, Lejeune, Bonhomme, Teillet, Tanzer, and Boiron, 1967). One additional interesting feature of this case is the presence of monoclonal hypergammaglobulinaemia not associated with myelomatous lesions. This abnormal protein was a 7S, IgG globulin with $\lambda$ chains.

Many cases in either healthy or diseased persons with monoclonal hypergammaglobulinaemia have been described. In such cases one cannot exclude the premyeloma or the 'lanthanic' myeloma state, since up to 18 years may elapse between the appearance of hypergammaglobulinaemia and overt myeloma (Kyle and Bayrd, 1966).

In our patient no bone lesions appeared even after three years, although the amount of pathological globulin increased significantly, a feature not commonly seen in the so-called essential monoclonal hypergammaglobulinaemia. The normal IgM and IgA immunoglobulins and the absence of Bence-Jones protein are in keeping with the findings of essential benign hypergammaglobulinaemia (Seligmann, 1967).

The coexistence of monoclonal hypergammaglobulinaemia of either the IgG of IgM variety and acute leukaemia is extremely rare although an extensive number of leukaemic patients has been investigated (Burkett, Fields, and Diggs, 1965; Danon et al, 1967; Fine, 1967; Hällén, 1966; Ritzmann, Garson, and Levin, 1962; Waldenström, 1962). Minimal increases in monoclonal IgM have also been reported by Marchal, Adida, and Fine (1964) in three cases of acute leukaemia. Among the reported cases there are not complete clinical or haematological details but it appears that all had a very short course except the patient reported by Hällén (1966), who lived for almost three years.

The case of Burkett et al (1965) is interesting because the increase in marrow plasma cells and M $\gamma$-globulin was associated with automatic remission of the leukaemia. Plasma cells and $\mathbf{M} \gamma$-globulin disappeared when relapse occurred.

Some believe that plasma cell infiltration and increase in gamma globulins represent an immune reaction to the primary neoplastic disease (Osserman and Takatsuki, 1965). Others have associated them with automatic remissions in leukaemia or have suggested the more benign and prolonged course of the haematological disorders (Brody et al, 1964).

It is conceivable that the long and benign course in this case may be related to the presence of the increased numbers of plasma cells and the $\mathbf{M} \gamma$ globulin component. If the presence of the $M$ component is not fortuitous, then one may think that it represents an antibody reaction to an unknown antigenic component of the leukaemic process. 
We wish to thank Professor N. Martin for the ultracentrifugation of the serum and Dr K. Kiossoglou for the chromosome analysis.

\section{References}

Azar, H. A., Hill, W. T., and Osserman, E. F. (1957). Malignant lymphoma and lymphatic leukemia associated with myeloma-type serum proteins. Amer. $J$. Med., 23, 239-249.

Baldini, M., Fudenberg, H. H., Fukutka, K., and Dameshek, W. (1959). The anemia of the $\mathrm{Di}$ Guglielmo syndrome. Blood, 14, 334-363.

Blair, T. R., Bayrd, E. D., and Pease, G. L. (1966). Atypical leukemia. J. Amer. med. Ass., 198, 21-24.

Brody, J. I., Beizer, L. H., and Schwartz, S. (1964). Multiple myeloma and the myeloproliferative syndromes. Amer. $J$. Med., 36, 315-319.

Burchenal, J. H. (1965). Long-term remissions of acute leukemia, spontaneous and induced. Ser. Hemat., 1, 47-56.

Burkett, L. L., Fields, M. L., and Diggs, L. W. (1965). A possible immene reaction producing spontaneous remission in leukemia. Blood, 25, 541-547.

Danon, F., Clauvel, J. P., and Seligmann, M. (1967). Les 'paraprotéines' de type $\lg \mathrm{G}$ et $\lg \mathrm{A}$ en dehors de la maladie de Kahler. Rev. Franç. étud. clin. biol., 12, 681-701.

Fairbanks, V. F., Shanbrom, E., Steinfeld, J. L., and Beutler, E. (1968). Prolonged remissions in acute myelocytic leukemia in adults. J. Amer. med. Ass., 204, 574-579.

Fine, J. M. (1967). Aspects actuels du diagnostic des dysglobulinémies (hyper-gamma globulinémies monoclonales). Transfusion (Paris), 10, 157-168.

Gomori, G. (1953). Chloracyl esters as histochemical substrates. J. Histochem. Cytochem., 1, 469-470.

Hällén, J. (1966). Discrete gamma-globulin (M) components in serum. Clinical study of 150 subjects without myelomatosis. Acta med. scand., suppl. 462.

Hayhoe, F. G. J., Quaglino, D., and Doll, R. (1964). The cytology and cytochemistry of acute leukaemias. Spec. Rep. Ser. med. Res. Coun. (Lond.), 304.

Kiossoglou, K. A., Mitus, W. J., and Dameshek, W. (1964). A direct method for chromosome studies of human bone marrow. Amer. J. clin. Path., 41, 183-187.

Kohn, J. (1960). Cellulose acetate electrophoresis and immunodiffusion techniques. In Chromatographic and Electrophoretic Techniques, edited by I. Smith, Vol. 2, pp. 56-90. Heinemann. London.

Kyle, R. A., and Bayrd, E. D. (1966). 'Benign' monoclonal gammopathy: a potentially malignant condition? Amer. $J$. Med., 40, 426-440.
Lortholary, P., Lejeune, F., Bonhomme, J., Teillet, F., Tanzer,(す) and Boiron, M. (1967). Contribution à l'étude cytochimique des leucémies aiguës dites a cellules monocytoỉdes. Noư Rev. franc. Hémat., 7, 711-720.

Mancini, G., Vaerman, J. P., Carbonara, A. O., and Heremañ J. B. (1964). Protides biol. Fluids, 11, 370-373.

Marchal, G., Adida, J., and Fine, J. M. (1964). Dysglobulinémies au cours des leucoses. Nouv. Rev. franc. Hémat., 4, 365-3

Nerenberg, S. T. (1966). Electrophoresis, F. A. Davis, Philadelp KPa

Osserman, E. F., and Takatsuki, K. (1965). Considerations regading the pathogenesis of the plasmacytic dyscrasias. Ser Haematol., 4, 28-49.

Perry, S., and Reynolds, J. (1956). Methyl-green-pyronin as differential nucleic acid stain for peripheral blood smeats. Blood, 2, 1132-1139.

Pratt, P. W., Estren, S., and Kochwa, S. (1968). Immunoglobutin abnormalities in Gaucher's disease. Report of 16 cases Blood, 31, 633-640.

Ritzmann, S. E., Garson, O. M., and Levin, W. C. (1962). Stem cell leukemia associated with gamma paraproteinemia. $C$ Res., 10, 293.

Ritzmann, S. E.. Stoufflet, E. J., Houston, E. W., and Levin, C. (1966). Coexistent chronic myelocytic leukenga, monoclonal gammopathy and multiple chromosom abnormalities. Amer. J. Med., 41, 981-989.

Seligmann, M. (1967). Les globulines myélomateuses ne sont pathognomoniques de la maladie de Kahler. Presse méch. 75, 1631-1632.

Waldenström, J. (1962). Hypergammaglobulinemia as a cliniea hematological problem: a study in gammopathies. Pror. Hemat., 3, 266-293.

Waldenström, J. (1964). The occurrence of benign, essential moñclonal (M Type), non-macro-molecular hyperglobuliner and its differential diagnosis. IV. Studies in the gamm pathies. Acta med. scand., 176, 345-365. 